\title{
ULTRAFINE PARTICLES (UFP) AND HEALTH EFFECTS. DANGEROUS. LIKE NO OTHER PM? REVIEW AND ANALYSIS
}

\author{
M. POLITIS* \\ C. PILINIS \\ T.D. LEKKAS
}

\author{
Water and Air Analysis Laboratory, Department of Environment, \\ University of Aegean, Mytilene, Greece
}

Received: $21 / 04 / 08$

Accepted: 30/06/08 *to whom all correspondence should be addressed: e-mail: mariospolitis@mac.com

\begin{abstract}
The goal of the current review is to present and analyze the known information proposed and discussed the last few years about UFP and their possible health effects. It includes references from 1992 to 2008. It also includes references from some fundamental studies in the 1970's and 1980's. The review and analysis of the health hazards induced by ultrafine particle exposure focuses on the; classification and characteristics of suspended particulate matter (PM), features and properties of PM and, specifically, ultrafine particles (UFP), the UFP movement and translocation from exposure sources in the environment to the human body and the ways of absorption and deposition within the human anatomy. Also, an extensive review of epidemiological, clinical and toxicology studies concerning possible health effects of UFP, is included. Finally, the most recent studies suggesting extrapulmonary effects and, especially, on the brain and central nervous system. Results have shown that there is significant analogy between UFP exposure and related adverse health effect risk in human beings. Cardiovascular and pulmonary systems seem to be the main targets of this exposure. New evidence shows accumulation of UFP in regions of the cerebellum, olfactory bulb and other areas of the central nervous system.
\end{abstract}

KEYWORDS: Air pollution, Ultrafine particles, Nanoparticles, Health effects, Cardiovascular system, Respiratoty system, Central Nervous System

\section{INTRODUCTION}

Particles in the atmosphere arise from natural sources, such as windborne dust, seaspray, and volcanoes, and from anthropogenic activities, such as combustion of fuels (Diapouli et al., 2008; Guo et al., 2008; Koi et al., 2008; Koulouri et al., 2008; Maraziotis et al., 2008; Polymeneas and Pilinis, 2008; Yang et al., 2008). Suspended particulate matter is technically defined as a suspension of fine solid or liquid particles in a gas condition (Seinfeld and Pandis, 2006). They decrease visibility (main source of haze) and stain the clothes. The ultrafine particulate matter can be breathed, led to and remained in pulmonary tissue, leading to enhanced probability of pulmonary disease and ultimately, lung damage.

Particulate matter is mainly classified by size and their division is as follows (Morawska et al., 2004): Coarse Particles (CP) include all particles that their aerodynamic diameter ${ }^{1}$ is greater than 2.5 micrometers and less than 10 micrometers. Fine Particles (FP) include all particles that their aerodynamic diameter is less than 2.5 micrometers and greater than 0.1 micrometers. Ultrafine Particles (UFP) include all particles that their aerodynamic diameter is less than 0.1 micrometers.

\footnotetext{
${ }^{1}$ Aerodynamic diameter: Is the diameter of a sphere with unit density and its mass is equal to the mass of the provided particle.
} 


\section{EXPOSURE ROUTES}

The main exposure route to ultrafine particles is through the respiratory system, that is, inhalation. When these particles are suspended in the air, there is an increased probability of inhaling them. How deep in the respiratory tree these particles can reach, how long they settle in and what they do when they deposit depends on their size, shape and the particulate matter density. What happens when they deposit in the respiratory system depends on the chemical and toxic properties of the matter (its composition). The particles can even cause problems when consumed as food components, such as coloring and anti-caking agents. These particles deposit in the lung cavity for a few months (WHO, 1997). Finally, one of the most dangerous UFP exposures occurs through smoking, since that helps transfer of dense quantities deep in the lung cavity.

\subsection{Absorption and Distribution}

UFP absorption seems to primarily happen through the lung, even though particle deposition can be observed anywhere in the body. The initial interaction of these particles with the lung epithelium causes several adverse effects and is mostly responsible for the observed cardiopneumatic pathology (Brunshidle et al., 2003). Because of the tiny size of the UFP, these can penetrate the lung epithelium and enter the bloodstream. From there, particles can be transferred to liver, bone marrow, brain and heart, leading to a systematic infection. Studies in dogs have confirmed this evidence. Studies in rats have shown a significant transfer of inhaled UFP to the liver (Brunshidle et al., 2003).

The particles deposit in the lung with one of the 4 following ways (CCOHS, 1999); Interception: A particle deposits by interception when it moves so close to the airway surface that the edge of the particle touches the surface. This deposition method is the main method for fibres such as asbestos. The length of the fibre determines the point where the particle will be intercepted and deposit. For example, fibres of $1 \mu \mathrm{m}$ diameter and $200 \mu \mathrm{m}$ length will be deposited in the bronchial tree; Impaction: When particles are suspended, they tend to travel alongside their original course. When a bend appears in the airways, for example, many particles do not spin, but rather crash or attach to a surface along their initial course. Impaction probability depends on air velocity and particle mass; Sedimentation: While particles travel with air, gravity forces and air resistance finally overcome their buoyancy (particle tendency to stay afloat). This results in particle deposition in a lung surface. This type of deposition is most common for bronchi and bronchioles. Sedimentation is not an important factor when the aerodynamic diameter of the particle is less than $0.5 \mu \mathrm{m}$. This is primarily the deposition mode for particles larger than $0.5 \mu \mathrm{m}$. The use of aerodynamic diameter allows the experts to compare particles of different size, shape and density with regards to how they will settle out of the air flow stream; Diffusion: The random movement of the particles is similar to gas molecules in the air when the particles are less than $0.5 \mu \mathrm{m}$. When the particles move randomly, they deposit on lung walls mainly by chance. This transfer motion is also known as Brownian motion ${ }^{2}$. The smaller the particles, the more vigorous the transfer motion is. Diffusion is the primary deposition mode in the small airways and the alveoli.

Depending on their size, UFP could deposit in nasal, tracheobronchial and alveolar regions by diffusion. As we observe from Figure 1, $90 \%$ of inhaled UFP close to $0.001 \mu \mathrm{m}$ in size deposit in the nasopharyngeal cavity (Swift et al., 1992; Cheng et al., 1996). Only $10 \%$ of the same size UFP deposit in the tracheobronchial regions and $0 \%$ (none) in lung alveoli. In control, UFP of 0.005 to $0.010 \mu \mathrm{m}$ in size deposit in all three lung regions with about $20-30 \%$ efficiency in every one. As far as UFP sizes $0.020 \mu \mathrm{m}$ are concerned, $50 \%$ of them deposit in alveolar region and only $10 \%$ in the tracheobronchial region and $10 \%$ in the nasopharyngeal cavity (ICRP, 1994). Therefore, we conclude that every one of the 3 lung regions is targeted differentially from the different sizes UFP (Figure 2). Their fate following deposition in the respiratory system seems to differ from that of coarse particles, at least with regards to solid and poorly soluble UFP (Oberdorster et al., 2003).

\footnotetext{
${ }^{2}$ Brownian Motion: This movement is owed by the collision of molecules of the air to very small suspended particles. The final movement of particles is accidental and distressed.
} 


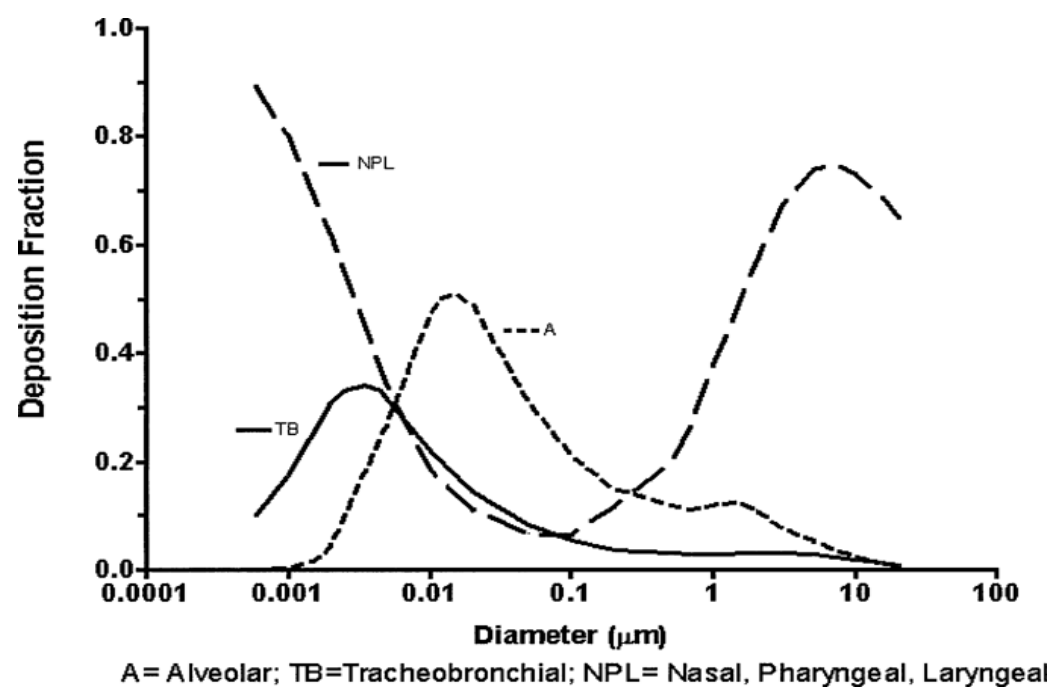

Figure 1. Model for fractional deposition of inhaled particles ranging from $0.006 \mu \mathrm{m}$ to $20 \mu \mathrm{m}$ in the nasopharyngeal region and the larynx (NPLO, in the tracheobronchial (TB) and alveolar

(A) region of the human respiratory tree during nasal breathing. Please note that in the ultrafine size range $(<0.1 \mu \mathrm{m})$ there are significant differences among the 3 regions as far as particle deposition probabilities are concerned.

(Oberdorster et al., 2003 taken from IRCP, 1994)

\section{BIOLOGICAL MARKERS OF THE DISEASE}

UFP inhalation is known to definitely affect two organ systems, the heart and the lungs. The lungs are affected by inhalation of carbonaceous ${ }^{3}$ UFP, which penetrate deep in the lung and deposit in the alveoli. Particles also deposit in the lung epithelium and can translocate to the intercellular space. Then, particles induce an inflammatory reaction. This inflammatory reaction can be measured by the number of polynucleated lymphocytes during pulmonary lavage, as shown in study with rats (Brunshidle et al., 2003). The extent of the reaction can be verified not by the amount of material retention in the lungs but by the occupied surface (Oberdorster, 1996). This inflammatory reaction appears as a series of events having health adverse effects, as found in another rat study. According to the Orberdorster model (Oberdorster, 1996), exposure to particulate matter leads to alveolar macrophage activation leading to acute inflammation and decreased removal. This results in acceleration of particle accumulation leading to chronic inflammation. This can cause lung fibrosis as well as mutations followed by epithelial cell hyperplasia. This, in turn, can induce metaplasia and tumour formation. In rats, the final stage could be carcinogenesis.

\section{RESEARCH}

\subsection{Epidemiological Studies}

In general, epidemiological studies attempt to correlate exposure to particulate matter (PM) with health effects, by examining (Morawska et al., 2004); particulate matter characteristics (e.g. size, concentration, composition) that could be responsible for the mortality and morbidity effects; social and medical factors that could aggravate the health risks when particle pollution increases; and possible pathophysiological mechanisms that could lead to death when humans are exposed to air particulate pollution.

A summary of the key epidemiological studies associating health effects with ultrafine particles is presented in Table 1 . The great majority of these studies were conducted within the framework of European ULTRA program by a group of researchers from Finland, Germany and the Netherlands.

\footnotetext{
${ }^{3}$ Carbonaceous: Organic and inorganic carbon compounds.
} 
Table 1. Summary of epidemiological studies on health effects from ultrafine particulate matter (UFP) exposure

\begin{tabular}{|c|c|c|c|c|}
\hline $\begin{array}{c}\text { REFERENCES } \\
\text { (LOCATION OF } \\
\text { STUDY) }\end{array}$ & $\begin{array}{l}\text { PARTICLE } \\
\text { TYPES }\end{array}$ & $\begin{array}{l}\text { EXPERIMENTAL } \\
\text { GROUPS }\end{array}$ & $\begin{array}{l}\text { EFFECTS } \\
\text { EXAMINED }\end{array}$ & FINDINGS AND CONCLUSIONS \\
\hline $\begin{array}{l}\text { Osunsanya et } \\
\text { al., } 2001 \\
\text { (UK) }\end{array}$ & $\begin{array}{ll}\text { - } & \mathrm{PM}_{10} \\
\text { - } & \mathrm{UFP}\end{array}$ & $\begin{array}{l}44 \text { adults ( }>50 \\
\text { years old) with } \\
\text { chronic pulmonary } \\
\text { disease }\end{array}$ & $\begin{array}{l}\text { Respiratory } \\
\text { symptoms }\end{array}$ & $\begin{array}{l}\text { No association was found between UFP, } \\
\text { respiratory symptoms and peak } \\
\text { expiratory flow (PEF). } \\
\text { A correlation was found between } \mathrm{PM}_{10} \\
\text { and respiratory symptoms. }\end{array}$ \\
\hline $\begin{array}{l}\text { Pekkanen et al., } \\
2002 \text { (Finland) }\end{array}$ & 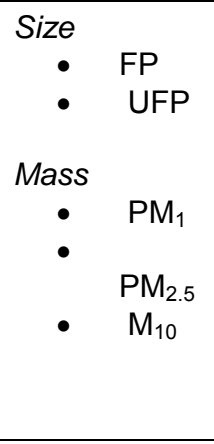 & $\begin{array}{l}45 \text { adults with } \\
\text { coronary disease }\end{array}$ & $\begin{array}{l}\text { Cardiovascular } \\
\text { symptoms }\end{array}$ & $\begin{array}{l}\text { Independent correlations were observed } \\
\text { between FP and UFP, at a ST segment } \\
\text { depression risk during repeated trials. No } \\
\text { correlation was found for the coarse } \\
\text { particles. The correlations tended to be } \\
\text { stronger between people that did not use } \\
\beta \text {-blockers. } \\
\text { Conclusions: The results showed that the } \\
\text { effect of atmospheric particle pollution on } \\
\text { cardiovasuclar symptoms is at least } \\
\text { indirect by increasing the sensitivity to } \\
\text { myocardiac ischaemia. }\end{array}$ \\
\hline $\begin{array}{l}\text { Penttinen, } 2001 \\
\text { (Finland) }\end{array}$ & $\begin{array}{cc}\begin{array}{cl}\text { Size } \\
\bullet\end{array} & \mathrm{FP} \\
\bullet & \mathrm{UFP} \\
\begin{array}{cc}\text { Mass } \\
\bullet\end{array} & \mathrm{PM}_{1} \\
\bullet & \mathrm{PM}_{2.5} \\
\text { - } & \mathrm{PM}_{10}\end{array}$ & $\begin{array}{l}54 \text { asthmatic adults, } \\
\text { non-smokers }\end{array}$ & $\begin{array}{l}\text { Respiratory } \\
\text { symptoms }\end{array}$ & $\begin{array}{l}\text { The daily average arithmetic particle } \\
\text { concentration, but not their mass, was } \\
\text { negatively connected with daily } \\
\text { divergences PEF. The largest effects } \\
\text { were seen with UFP. However, the UFP } \\
\text { effects could not be clearly isolated from } \\
\text { other traffic pollutants, such as nitric } \\
\text { oxide, nitrogen dioxide and carbon } \\
\text { monoxide. No correlation was found for } \\
\text { respiratory symptoms or medicine use. } \\
\text { Particle mass measurements could be } \\
\text { strongly affected by mechanically or soil } \\
\text { produced particles that cannot be } \\
\text { correlated with health adverse effects. } \\
\text { Therefore, monitoring air quality should } \\
\text { include particle number concentration, } \\
\text { which primarily reflects the UFP. }\end{array}$ \\
\hline $\begin{array}{l}\text { Wichmann et al., } \\
2000 \text { (Germany) }\end{array}$ & 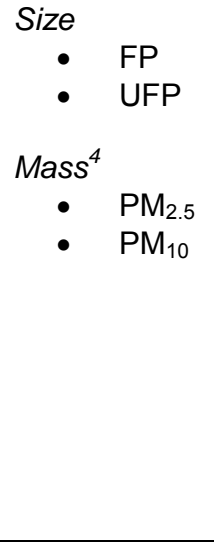 & General population & $\begin{array}{l}\text { Cardiovascular } \\
\& \\
\text { Respiratory } \\
\text { mortality }\end{array}$ & $\begin{array}{l}\text { It was established that FP and UFP are } \\
\text { associated with increased mortality. } \\
\text { However, the PF had more direct effects } \\
\text { compared to the UFP, which showed a } \\
\text { four-day delay in the concentration- } \\
\text { mortality relationship. } \\
\text { Furthermore, the direct results were more } \\
\text { evident in respiratory cases, while the } \\
\text { delayed effects were more evident in } \\
\text { cardiovascular cases. } \\
\text { Conclusions: FP could be used as an } \\
\text { index for UFP. Moreover, UFP } \\
\text { concentration seems to continually } \\
\text { increase from } 1991 / 92 \text { while FP appears } \\
\text { to decrease. }\end{array}$ \\
\hline
\end{tabular}

\subsection{Clinical Studies}

The controlled exposure studies referred in this chapter fall in two categories. The first category is related with dosimetry. The dosimetry studies are shown in Table 2. These studies have assessed different dosimetric aspects of ultrafine particle inhalation including the possibility of crossing the air-blood lung barrier and the resulting pathological consequences. The second category of the studies belongs to the Frampton-proposed type. These examine

\footnotetext{
${ }^{4}$ Measured from particle number.
} 
whether and up to which point the inhaled ultrafine particle can cause acute lung damage or/and inflammation as well as other non-respiratory health adverse effects. These studies are shown in Table 3.

Table 2. Dosimetry

\begin{tabular}{|c|c|c|c|c|}
\hline REFERENCES & $\begin{array}{l}\text { RESEARCH } \\
\text { OBJECTIVE }\end{array}$ & $\begin{array}{c}\text { EXPERIMENTAL } \\
\text { GROUPS }\end{array}$ & $\begin{array}{l}\text { EXPOSURE } \\
\text { DETAILS }\end{array}$ & RESULTS \\
\hline $\begin{array}{l}\text { Brown et al., } \\
2002\end{array}$ & $\begin{array}{l}\text { To characterize } \\
\text { the deposition } \\
\text { and removal of } \\
\text { UF particles } \\
\text { (technetium- } \\
99 \mathrm{~m} \text { ) in COPD } \\
\text { patients and } \\
\text { healthy } \\
\text { volunteers. }\end{array}$ & 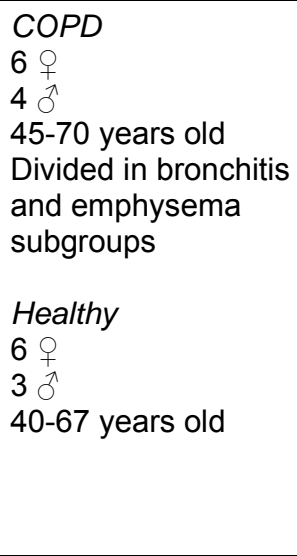 & $\begin{array}{l}\text { Inhalation through } \\
\text { a mouthpiece } \\
\text { Technetium } \\
\text { particles-99 m } \\
\text { CMD }=0.033 \pm 2 \mu \mathrm{m} \\
\text { Inhalation } \\
\text { continued until } \\
25 \mathrm{mCi} \text { were } \\
\text { deposited in the } \\
\text { lung }\end{array}$ & $\begin{array}{l}\text { Scintigram } \\
\text { - No hepatic accumulation } \\
\text { Removal was not significantly } \\
\text { different between healthy and } \\
\text { COPD groups } \\
\text { - The C/Po index increased in the } \\
\text { bronchitis subgroup of the } \\
\text { COPD group compared to the } \\
\text { healthy group } \\
\text { Deposition } \\
\text { Significantly greater in } \\
\text { bronchitis subgroup compared } \\
\text { to the healthy and emphysema } \\
\text { subgroups. }\end{array}$ \\
\hline $\begin{array}{l}\text { Kim and Jaques, } \\
2000\end{array}$ & $\begin{array}{l}\text { To find data for } \\
\text { human lung } \\
\text { region-dose } \\
\text { relationship }\end{array}$ & $\begin{array}{l}11 \text { o } \\
11 \text { o } \\
20-40 \text { years old } \\
\text { Non-smokers or } \\
\text { non-smokers the } \\
\text { last } 5 \text { years }\end{array}$ & $\begin{array}{l}\text { Inhalation through } \\
\text { a mouthpiece. } \\
\text { Bolus dose of oil } \\
\text { particles } \\
\text { condensed in } \\
\text { metallic nuclei } \\
\text { Particle size of } \\
0.04,0.06,0.08 \\
\text { and } 0.1 \mu \mathrm{m} \\
\text { Respirable volume } \\
500 \mathrm{ml} \text { and flow } \\
\text { rate } 250 \mathrm{ml} \mathrm{s}^{-1}\end{array}$ & $\begin{array}{l}\text { Regional deposition varies greatly } \\
\text { along the depth of the lung } \\
\text { independent of molecule size. }\end{array}$ \\
\hline
\end{tabular}

\subsection{Toxicological Studies}

In-vivo animal studies conducted in live animals demonstrate that there is a greater tendency for generation of inflammation following ultrafine particle (UFP) exposure. This result, as seen with the aforementioned studies, correlates with increased particle surface area. These studies are shown in Table 4.

In-vitro animal studies (Table 5) have examined several different cell types from animals as well as humans. In all cases inflammation was the end-point assessed. In studies where DEP were included, the results seem to primarily associate with the absorbed compounds. These studies also showed that particles persist in tissues as relatively large groups of single particles. The smaller the particles the easier for them to penetrate the epithelium. The particles are also capable of increasing inflammatory cytokine production. Agents such as interleukin -8 and interleukin -10 are produced. However, in-vitro studies do not allow the assessment of the complex interactions of these cytokines since they are conducted on simple cell types and do not assess the intracellular mechanisms that determine the operations of these agents in the whole organism. As with other studies, the determining factor for the effects of ultrafine particles is the particle surface area and not their weight. 
Table 3. Controlled exposure studies to ultrafine particles (UFP)

\begin{tabular}{|c|c|c|c|c|}
\hline REFERENCES & $\begin{array}{l}\text { RESEARCH } \\
\text { OBJECTIVE }\end{array}$ & $\begin{array}{l}\text { EXPERIMENTAL } \\
\text { GROUPS }\end{array}$ & $\begin{array}{l}\text { EXPOSURE } \\
\text { DETAILS }\end{array}$ & RESULTS \\
\hline $\begin{array}{l}\text { Frampton et al., } \\
1992\end{array}$ & $\begin{array}{l}\text { To determine } \\
\text { whether } \\
\text { exposure to } \\
\mathrm{H}_{2} \mathrm{SO}_{4} \\
\text { particles } \\
\text { induces } \\
\text { alveolar } \\
\text { reaction }\end{array}$ & $\begin{array}{l}2 \text { o } \\
10 \stackrel{1}{\delta} \\
\text { Healthy, non- } \\
\text { smokers } \\
20-39 \text { years old }\end{array}$ & $\begin{array}{ll}\text { - } & \text { Gas chamber } \\
\text { exposure } \\
\text { - } \mathrm{H}_{2} \mathrm{SO}_{4} \text { particles } \\
\text { with average } \\
\text { diameter } 0.9 \mu \mathrm{m} \\
\text { - } \\
\text { Exposure } \\
\text { during exercise } \\
\text { - Double-blind } \\
\text { study }\end{array}$ & $\begin{array}{l}\text { Symptoms } \\
\text { - Four detected an odor } \\
\text { - Three had cough and four felt } \\
\text { discomfort in the neck during } \\
\text { exposure } \\
\text { Plethysmography } \\
\text { - No change in FVC and FEV } 1 \\
\text { immediately or } 18 \text { hours following } \\
\text { exposure } \\
\text { Bronchoalveolar lavage } \\
\text { - No significant difference in various } \\
\text { cell counts } \\
\text { Alveolar macrophage function } \\
\text { - No statistical difference was found in } \\
\text { macrophage function }\end{array}$ \\
\hline $\begin{array}{l}\text { Holgate et al., } \\
2002\end{array}$ & $\begin{array}{l}\text { To assess the } \\
\text { effect of short- } \\
\text { term exposure } \\
\text { to diesel } \\
\text { exhausts } \\
\text { on induction of } \\
\text { airway } \\
\text { inflammation. } \\
\text { The objective } \\
\text { of the study } \\
\text { was to assess } \\
\text { whether the } \\
\text { observed } \\
\text { increased } \\
\text { sensitivity to } \\
\text { atmospheric } \\
\text { pollutants in } \\
\text { asthmatics } \\
\text { could be } \\
\text { explained by } \\
\text { neutrophil- } \\
\text { mediated } \\
\text { inflammation } \\
\text { orland } \\
\text { enhanced } \\
\text { effect of } \\
\text { airway } \\
\text { inflammation, } \\
\text { due to diesel } \\
\text { exhaust } \\
\text { exposure }\end{array}$ & 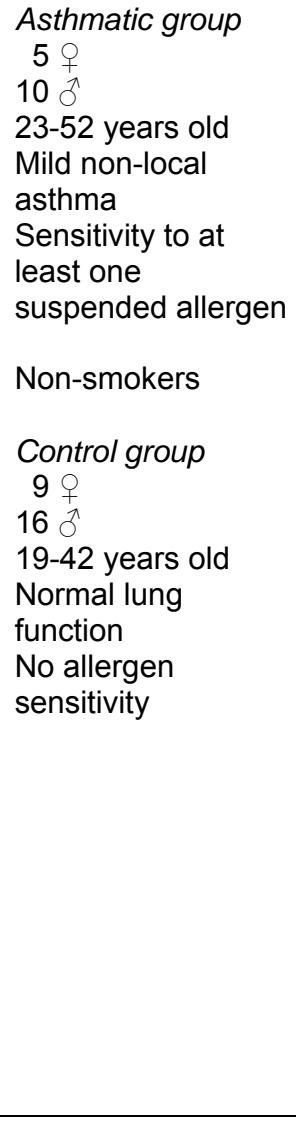 & $\begin{array}{l}\text { - Gas chamber } \\
\text { exposure } \\
\text { - Diesel exhaust } \\
\text { exposure } \\
\text { - Double-blind } \\
\text { study }\end{array}$ & $\begin{array}{l}\text { Lung function } \\
\text { - A mild but statistically significant } \\
\text { increase in airway resistance at the } \\
\text { end of exposure in the asthmatic } \\
\text { group } \\
\text { - A mild but statistically significant } \\
\text { increase in airway resistance at the } \\
\text { end of and one hour after exposure in } \\
\text { the control group } \\
\text { - No significant change in FVC or } \\
\text { FEV } 1 \\
\text { Peripheral blood: } \\
\text { - No significant change } \\
\text { Cleared blood before and after exposure } \\
\text { Bronchoalveolar lavage: } \\
\text { - Significantly more neutrophils in } \\
\text { the control but not the asthmatic } \\
\text { group } \\
\text { - Significantly higher IL-6 and IL-8 } \\
\text { levels in the control but not the } \\
\text { asthmatic group } \\
\text { Significantly higher leukocyte } \\
\text { counts in the control group } \\
\text { Significantly lower macrophage } \\
\text { counts in the control group }\end{array}$ \\
\hline $\begin{array}{l}\text { Salvi et al., } \\
1999\end{array}$ & $\begin{array}{l}\text { To test the } \\
\text { hypothesis } \\
\text { that diesel } \\
\text { exhaust } \\
\text { exposure can } \\
\text { induce } \\
\text { inflammatory } \\
\text { reactions in } \\
\text { airways and } \\
\text { peripheral } \\
\text { blood }\end{array}$ & $\begin{array}{l}4 \text { ㅇ } \\
11 \stackrel{1}{\circ} \\
21-28 \text { years old } \\
\text { Healthy non- } \\
\text { smokers }\end{array}$ & $\begin{array}{ll}\text { - } & \text { Gas chamber } \\
\text { exposure } \\
\text { - } \\
\text { DEP and } \\
\mathrm{PM}_{10} \text { particles } \\
\text { and clean air } \\
\text { (control) } \\
\text { - Blind study }\end{array}$ & $\begin{array}{l}\text { Spirometry: } \\
\text { - No statistical difference in the } \\
\text { parameters } \\
\text { Peripheral blood: } \\
\text { - In the DEP exposed group, the } \\
\text { neutrophils and platelets were } \\
\text { increased } \\
\text { - In the DEP-exposed group the } \\
\text { cellular HLA-DR }{ }^{+} \text {was found less } \\
\text { Bronchoalveolar lavage: } \\
\text { - In the DEP exposed group there } \\
\text { was a significantly greater } \\
\text { neutrophil number } \\
\end{array}$ \\
\hline
\end{tabular}


Table 4. Summary of in-vivo animal studies

\begin{tabular}{|c|c|c|c|c|}
\hline REFERENCES & $\begin{array}{l}\text { EXPERIME } \\
\text { NTAL } \\
\text { GROUPS }\end{array}$ & EFFECT & $\begin{array}{l}\text { RESEARCH } \\
\text { STUDY } \\
\text { DESCRIPTION }\end{array}$ & FINDINGS - CONCLUSIONS \\
\hline $\begin{array}{l}\text { Baggs et al., } \\
1997\end{array}$ & Rats & $\begin{array}{l}\text { Inflammation } \\
\text { (Lungs) }\end{array}$ & $\begin{array}{l}344 \text { rats were } \\
\text { exposed for six } \\
\text { hours daily, } 5 \\
\text { days a week, for } 3 \\
\text { months to } \\
\text { 1) filtered air } \\
\text { (control) } \\
\text { 2) } \mathrm{TiO}_{2}-\mathrm{D} \text {, particle } \\
\text { size } 0.02 \mu \mathrm{m} \\
\text { 3) } \mathrm{TiO}_{2}-\mathrm{F}, 0.25 \mu \mathrm{m} \\
\text { 4) } \mathrm{Crystal} \mathrm{SiO}_{2} \text {, } \\
\text { 0.8 } \mu \mathrm{m}\end{array}$ & $\begin{array}{l}\text { Within } 6 \text { months following exposure: } \text { - In } \mathrm{SiO}_{2} \text {, there was mild focal } \\
\text { interstitial fibrosis and serious } \\
\text { focal alveolitis } \\
\text { - In } \mathrm{TiO}_{2}-\mathrm{D} \text { and } \mathrm{TiO}_{2}-\mathrm{F} \text {, there } \\
\text { was slightly less fibrosis. } \\
\text { Within } 1 \text { year following exposure: } \\
\text { - } \quad \text { the fibrosis was still present but } \\
\text { decreased in the } \mathrm{SiO}_{2} \text { group } \\
\text { - the percentage of interstitial } \\
\text { fibrosis, due to treatment with } \\
\mathrm{TiO}_{2}-\mathrm{D} \text { and } \mathrm{TiO}_{2}-\mathrm{F} \text {, returned to } \\
\text { pre-treatment levels } \\
\text { Conclusions: Inhaled UFP TiO } \\
\text { lead to greater lung inflammatory } \\
\text { response compared to larger } \\
\text { particles. }\end{array}$ \\
\hline $\begin{array}{l}\text { Brown et al., } \\
2001\end{array}$ & Rats & Respiratory & $\begin{array}{l}\text { Examined pre- } \\
\text { inflammatory } \\
\text { reactions to } \\
\text { different } \\
\text { polystyrene } \\
\text { particle size }\end{array}$ & $\begin{array}{l}\text { There was significantly greater } \\
\text { neutrophil inflow to the lung following } \\
\text { instillation of polystyrene particles } \\
0.064 \mu \mathrm{m} \text { compared to } 0.202 \text { and } \\
0.535 \mu \mathrm{m} \text { particles. } \\
\text { Conclusions: The results suggest that } \\
\text { UFP composed of low-toxicity } \\
\text { material such as polystyrene induce } \\
\text { pre-inflammatory activity due to their } \\
\text { large surface area. }\end{array}$ \\
\hline $\begin{array}{l}\text { Osier \& } \\
\text { Oberdorster, } \\
1997\end{array}$ & Rats & Inflammation & $\begin{array}{l}\text { Rat reaction to } \\
\text { inhalation } \\
\text { exposure } \\
\text { (endotracheal) of } \\
\text { FP }(0.25 \mu \mathrm{m}) \text { and } \\
\text { UFP }(0.021 \mu \mathrm{m}) \\
\text { titanium dioxide } \\
\text { was compared to } \\
\text { rats exposed to } \\
\text { similar doses of } \\
\text { endotracheal } \\
\text { instillations. }\end{array}$ & $\begin{array}{l}\text { The animals exposed to particles } \\
\text { through inhalation showed decreased } \\
\text { respiratory reaction (measured from } \\
\text { bronchoalveolar lavage), both in the } \\
\text { seriousness and persistence, } \\
\text { compared to rats exposed to instilled } \\
\text { particles. These differences could be } \\
\text { accounted by variations in dose, } \\
\text { particle distribution or differential } \\
\text { removal between the two routes of } \\
\text { administration. }\end{array}$ \\
\hline $\begin{array}{l}\text { Takenaka et al., } \\
2000\end{array}$ & $\begin{array}{l}\text { Rats \& in- } \\
\text { vitro } \\
\text { (macrophag } \\
\text { e cells) }\end{array}$ & Inflammation & $\begin{array}{l}\text { The fate of UFP } \\
\text { aggregates }(\mathrm{Ag}) \\
\text { was examined in } \\
\text { macrophages, in } \\
\text { the dish and in the } \\
\text { live organism. }\end{array}$ & $\begin{array}{l}\text { Both in the dish and the live } \\
\text { organism, the studies showed that } \mathrm{Ag} \\
\text { particle aggregates remained in their } \\
\text { targets for a period at least } 7 \text { days. }\end{array}$ \\
\hline
\end{tabular}

\section{UFP IN BRAIN AND CENTRAL NERVOUS SYSTEM}

In 2002, Oberdorster et al, presented the hypothesis that UFP could enter the brain and central nervous system (CNS). This could occur through some type of nerve (e.g. olfactory) or through the blood-brain barrier or through some other way (Oberdorster and Utell, 2002). Depending on their size, UFP could deposit in nasal, tracheobronchial and alveolar regions by diffusion. Previous studies in rats and mice have showed that UFP could transfer to interstitial space in the pulmonary system as well as in extra-pulmonary systems, such as the liver, 4 to 24 hours following exposure. There are also indications that the olfactory bulb in the brain is a target. It was found in a pilot study with inhaled ${ }^{13} \mathrm{C}$ UFP that there is a significant increase of ${ }^{13} \mathrm{C}$ in the rat olfactory bulb, which led to the hypothesis that there are other translocation 
routes of solid UFP besides the blood stream. These could be neural pathways from nasal olfactory mucosa deposition via the olfactory nerve (Oberdorster et al., 2003).

In the following Table 6 we see a summary of studies concerning the possible transfer of ultrafine particles to the brain and central nervous system.

Table 5. Summary of in-vitro animal studies

\begin{tabular}{|c|c|c|c|c|}
\hline REFERENCES & $\begin{array}{l}\text { EXPERIME } \\
\text { NTAL } \\
\text { GROUPS }\end{array}$ & EFFECT & $\begin{array}{l}\text { RESEARCH STUDY } \\
\text { DESCRIPTION }\end{array}$ & FINDINGS AND CONCLUSIONS \\
\hline $\begin{array}{l}\text { Beck-Speier et } \\
\text { al., } 2001\end{array}$ & $\begin{array}{l}\text { In-vitro } \\
\text { (immunized } \\
\text { cells) }\end{array}$ & $\begin{array}{l}\text { Non-immune } \\
\text { cellular reactions }\end{array}$ & $\begin{array}{l}\text { The response of non- } \\
\text { immune cells to } \\
\text { exposure to } 0.077 \mu \mathrm{m} \\
\text { elemental carbon } \\
\text { aggregates and } \\
\text { titanium dioxide } \\
\text { particles } 0.021 \mu \mathrm{m} \text { was } \\
\text { assessed, by the } \\
\text { release of lipid } \\
\text { mediators from alveolar } \\
\text { macrophages. }\end{array}$ & $\begin{array}{l}\text { The results show that the surface } \\
\text { area rather than mass concentration } \\
\text { determines the effects of UFP }\end{array}$ \\
\hline $\begin{array}{l}\text { Boland et al., } \\
2000\end{array}$ & $\begin{array}{l}\text { In-vitro } \\
\text { (human } \\
\text { bronchial } \\
\text { epithelial } \\
\text { cells) } \\
\end{array}$ & $\begin{array}{l}\text { Inflammation } \\
\text { (Lungs) }\end{array}$ & $\begin{array}{l}\text { The mechanisms } \\
\text { behind the increase } \\
\text { and release of GM-F, } \\
\text { detached from DEPs, } \\
\text { were studied }\end{array}$ & $\begin{array}{l}\text { The increase in GM-F release came } \\
\text { primarily from available organic } \\
\text { compounds and the effect of intrinsic } \\
\text { DEP requires particle endocytosis }\end{array}$ \\
\hline $\begin{array}{l}\text { Kawasaki et al., } \\
2001\end{array}$ & $\begin{array}{l}\text { In-vitro } \\
\text { (human } \\
\text { cells) }\end{array}$ & $\begin{array}{l}\text { Inflammation } \\
\text { (Lungs) }\end{array}$ & $\begin{array}{l}\text { The pre-inflammatory } \\
\text { effects of DEP on the } \\
\text { respiratory track were } \\
\text { studied. }\end{array}$ & $\begin{array}{l}\text { It was established that DEP increased } \\
\text { cytokine (inflammatory mediators) } \\
\text { production from human epithelial cells } \\
\text { of airways }\end{array}$ \\
\hline $\begin{array}{l}\text { Kim et al., } \\
2003\end{array}$ & $\begin{array}{l}\text { In-vitro } \\
\text { (collagen } \\
\text { gel) }\end{array}$ & Inflammation & $\begin{array}{l}\text { The three-dimensional } \\
\text { collagen gel contraction } \\
\text { template was used to } \\
\text { assess whether } \\
\text { carbonated UFP could } \\
\text { affect tissue repair }\end{array}$ & $\begin{array}{l}\text { The results show the ability of UFP to } \\
\text { alter the tissue repair process }\end{array}$ \\
\hline $\begin{array}{l}\text { Stone et al., } \\
2000\end{array}$ & Rats & Inflammation & $\begin{array}{l}\text { It was examined } \\
\text { whether UFP could } \\
\text { induce alterations in } \\
\text { calcium flow in } \\
\text { macrophages }\end{array}$ & $\begin{array}{l}\text { BC UF particles are likely to activate } \\
\text { calcium flow, partially through } \\
\text { oxidative pressure. }\end{array}$ \\
\hline $\begin{array}{l}\text { Timblin et al., } \\
2002\end{array}$ & $\begin{array}{l}\text { In-vitro } \\
\text { (alveolar } \\
\text { epithelial } \\
\text { cells) }\end{array}$ & Inflammation & $\begin{array}{l}\text { The dose-dependent } \\
\text { proliferation and } \\
\text { apoptosis after } \\
\text { exposure of alveolar } \\
\text { epithelium to PM or } \\
\text { UFCB or to a PM } \\
\text { component was } \\
\text { illustrated. }\end{array}$ & $\begin{array}{l}\text { It was established that the ultrafine } \\
\text { size of particulate matter is very } \\
\text { important for its bio-activity. }\end{array}$ \\
\hline $\begin{array}{l}\text { Wilson et al., } \\
2002\end{array}$ & In vitro & Inflammation & $\begin{array}{l}\text { The interactions } \\
\text { between transition salts } \\
\text { and UFCB were } \\
\text { measured }\end{array}$ & $\begin{array}{l}\text { In all experimental systems used, the } \\
\text { ultrafine carbon black was found to be } \\
\text { more active than the respective fine. }\end{array}$ \\
\hline
\end{tabular}


Table 6. Studies related to UFP translocation to the Brain and CNS

\begin{tabular}{|c|c|c|c|}
\hline REFERENCES & $\begin{array}{l}\text { EXPERIMENTAL } \\
\text { GROUPS }\end{array}$ & $\begin{array}{l}\text { RESEARCH } \\
\text { EVIDENCE }\end{array}$ & FINDINGS AND CONCLUSIONS \\
\hline $\begin{array}{l}\text { Dorman et al., } \\
2004\end{array}$ & Rats & $\begin{array}{l}\text { Particles: } \\
\text { Mn sulfate } \\
\text { Mn phosphate }\end{array}$ & $\begin{array}{l}\text { - No indication of alteration in brain GFAP } \\
\text { levels following exposure. } \\
\text { Mn transfer to the olfactory bulb, } \\
\text { cerebellum and striatum was measured. } \\
\text { A small increase in Mn content was } \\
\text { found only in the olfactory bulb. }\end{array}$ \\
\hline $\begin{array}{l}\text { Henriksson and } \\
\text { Tjalve, } 2000\end{array}$ & Rats & $\begin{array}{l}\text { Particles: } \\
\text { Mn chloride } \\
\text { Nasal instillation }\end{array}$ & $\begin{array}{l}\text { Changes in Glial Fibrilliary Acidic Protein } \\
\text { (GFAP) and S-100b were reported, markers of } \\
\text { astrocyte activation in different brain regions. }\end{array}$ \\
\hline $\begin{array}{l}\text { Oberdorster et al., } \\
2004\end{array}$ & Rats & $\begin{array}{l}\text { Particles: } \\
{ }^{13} \mathrm{C}, \\
0.035 \mu \mathrm{m} \\
\text { Inhalation and full body } \\
\text { exposure }\end{array}$ & $\begin{array}{l}\text { Particle accumulation in the olfactory bulb was } \\
\text { observed. }\end{array}$ \\
\hline $\begin{array}{l}\text { Tjalve et al., } \\
1995\end{array}$ & Esox Lucius & $\begin{array}{l}\text { Particles: } \\
\text { Non - ionic } \\
\text { Nasal instillation }\end{array}$ & $\begin{array}{l}\text { lonic Mn was shown to have the ability to pass } \\
\text { through synaptic junctions and migrate from } \\
\text { the olfactory region to more distant regions, } \\
\text { including the hypothalamus. }\end{array}$ \\
\hline $\begin{array}{l}\text { Tjalve et al., } 1996 \\
\text { Henriksson and } \\
\text { Tjalve, } 1999\end{array}$ & Rats & $\begin{array}{l}\text { Particles: } \\
\text { Mn compounds } \\
\text { Inhalation or/and full } \\
\text { body exposure }\end{array}$ & $\begin{array}{l}\text { Mn compound transfer was observed from the } \\
\text { nose through the olfactory nerve axons to the } \\
\text { olfactory bulb. }\end{array}$ \\
\hline $\begin{array}{l}\text { Bodian and Howe } \\
\text { 1941a; } 1941 \mathrm{~b} \\
\text { DeLorenzo } 1970\end{array}$ & $\begin{array}{l}\text { Non-human } \\
\text { mammals }\end{array}$ & $\begin{array}{l}\text { Particles: } \\
\text { Polio virus, } 0.030 \mu \mathrm{m} \\
\& \\
\text { Collagen-like } \\
0.050 \mu \mathrm{m}\end{array}$ & $\begin{array}{l}\text { Transfer ability of solid ultrafine particles was } \\
\text { shown alongside axons of olfactory nerves to } \\
\text { the olfactory bulb. }\end{array}$ \\
\hline
\end{tabular}

\section{FINDINGS AND CONCLUSIONS}

The epidemiological studies have provided evidence that there is serious health hazards associated with the human exposure to environmental levels of particulate matter found in the urban centres at concentrations below the acceptable particulate matter levels (US EPA, 1996). Even though various reactions to components of environmental particulate matter have been hypothesized to contribute to the reported health hazards, the related published toxicology and controlled human clinical studies have not pinpointed an acceptable mechanism that could explain how such low levels of particulate matter concentration could cause the health hazards reported in the epidemiological studies. However, the toxicology studies tend to show that particles become more toxic per mass unit with decreasing size. This makes UFP a primary target for further research. Consequently, our attention turns to the surface area or the particle number, rather than mass concentration.

The studies on particle mass concentration $\left(\mathrm{PM}_{10}\right.$ and $\left.\mathrm{PM}_{2.5}\right)$ show that there is no lower limit for particle mass below which there is no health danger. This is presented in the guidelines of the World Health Organization for air quality (WHO 1999b), which has a linear relationship between $\mathrm{PM}_{10}$ and $\mathrm{PM}_{2.5}$ with various health indicators (including mortality, hospital admissions, bronchodilators use, symptom aggravation, cough and peak expiratory flow) for concentration levels from 0 to $200 \mu \mathrm{g} \mathrm{m}^{-3}$.

To summarize part of the aforementioned knowledge, the following Table 7 includes the systems in which the particles could be accumulated, most of the known signs, symptoms and diseases that born or altered by human exposure to suspended particulate matter, and especially, ultrafine particles. 
Table 7. Possible effects of PM in human systems

\begin{tabular}{|c|c|}
\hline System & Possible Effects \\
\hline $\begin{array}{l}\text { Respiratory } \\
\text { System }\end{array}$ & $\begin{array}{l}\text { - } \quad \text { Some epidemiological studies showed adverse effects only in compromised people. } \\
\text { - } \quad \text { Changes in lung function and increase in respiratory pathologic symptoms. } \\
\text { - } \quad \text { Changes in lung histology and structure } \\
\text { - } \quad \text { Asthma exacerbation } \\
\text { - } \quad \text { Pulmonic bronchitis } \\
\text { - } \quad \text { Macrophage, neutrophil and monocyte concentrations were significantly greater in the } \\
\text { - } \quad \text { Significantly higher IL-6 and IL-8 levels in the bronchoalveolar lavage of exposed people } \\
\text { - } \quad \text { Significantly higher leukocyte counts in the control group in the bronchoalveolar lavage of exposed } \\
\text { - } \quad \text { Mild focal interstitial fibrosis } \\
\text { - } \quad \text { Inflammatory reaction in the lung } \\
\text { Lung disease exacerbation (as corroborated by increased numbers of hospital admissions, visit to } \\
\text { emergency room, school absences, missed work-hours, days of reduced activity due to health } \\
\text { - } \quad \text { problems) } \\
\text { Increased respiratory morbidity and mortality in sensitive populations }\end{array}$ \\
\hline $\begin{array}{l}\text { Cardiovascular } \\
\text { System }\end{array}$ & $\begin{array}{l}\text { - The whole process predisposes the person to cardiovascular damage: } \\
\text { 1. Damage in epithelial cells from reactive oxygen species and activation of regulation factors. } \\
\text { 2. Activation of vascular endothelium and circulatory polymorphonuclear leukocytes. } \\
\text { 3. Inflammatory cell migration from the blood to tissues. } \\
\text { 4. Up-regulation of adhesive molecules in vascular endothelium. } \\
\text { 5. Increased secretion of interleukin }-6 \text { (IL-6) and tissue factors through activation of blood } \\
\text { factors. } \\
\text { 6. Mononucleated cells activate C-reactive protein (CRP), amyloid A and fibrinogen. } \\
\text { - Cardiac ischemic disease } \\
\text { - Heart attack } \\
\text { - ST segment depression risk } \\
\text { - Increasing the sensitivity to myocardial ischemia. } \\
\text { Heart disease exacerbation (as corroborated by increased numbers of hospital admissions, visit to } \\
\text { emergency room, school absences, missed work-hours, days of reduced activity due to health } \\
\text { problems) } \\
\text { Increased cardiovascular morbidity and mortality in sensitive populations }\end{array}$ \\
\hline $\begin{array}{l}\text { Gastrointestinal } \\
\text { System }\end{array}$ & $\begin{array}{l}\text { - } \quad \text { UFP are related to Crohn's disease (chronic recurrent inflammatory intestinal disease). } \\
\text { - } \quad \text { UFP, deposited and accumulated in the Liver } \\
\text { - } \quad \text { UFP, deposited and accumulated in the bladder }\end{array}$ \\
\hline $\begin{array}{l}\text { Circulatory } \\
\text { System }\end{array}$ & $\begin{array}{l}\text { - } \quad \text { Changes in blood indicators } \\
\text { - } \quad \text { UPF penetrate very deep and fast in the interstitial space and could enter blood circulation }\end{array}$ \\
\hline $\begin{array}{l}\text { Nervous } \\
\text { System }\end{array}$ & $\begin{array}{l}\text { CNS } \\
\text { - Mn ultrafine particles translocated to the olfactory bulb, cerebellum and striatum } \\
\text { - } \quad \text { Particle accumulation in the olfactory bulb was observed } \\
\text { - } \quad \text { lonic Mn was shown to have the ability to pass through synaptic junctions and migrate from the } \\
\text { olfactory region to more distant regions, including the hypothalamus } \\
\text { - Transfer ability of solid ultrafine particles was shown alongside axons of olfactory nerves to the } \\
\text { olfactory bulb } \\
\text { ANS } \\
\text { - Alterations in Autonomic Nervous System (ANS) function, and changes in cardiovascular risk } \\
\text { factors such as arterial blood pressure, C-reactive protein and endothelial dysfunction }\end{array}$ \\
\hline Urine & $\begin{array}{l}\text { Thin layer chromatography (TLC) showed the presence of a soluble }{ }^{99 m} \mathrm{Tc} \text { type and the absence of any } \\
{ }_{99 \mathrm{~m}} \mathrm{Tc} \text { type bound to carbon particles }\end{array}$ \\
\hline $\begin{array}{l}\text { General } \\
\text { Symptoms }\end{array}$ & $\begin{array}{ll}\text { - } & \text { Cough } \\
\text { - } & \text { Fatigue } \\
\text { - } & \text { Muscle aches } \\
\text { - } & \text { Discomfort in the neck } \\
\text { - } & \text { Premature mortality }\end{array}$ \\
\hline
\end{tabular}


From the above comprehensive literature review, we conclude that there is a correlation between UFP and alterations in morbidity and mortality indices because of respiratory and cardiac effects in the elderly and susceptible groups. There is also a correlation with increased proportion of asthma episodes and hospital admissions. Ultrafine particle (UFP) exposure could be responsible for increased medicine use, missed work-hours and school absences.

Of course, it is not only the respiratory and cardiovascular system that have been hypothesized and studied as target systems of ultrafine particles (UFP). The past few years, researchers throughout the world generate more and more data suggesting that the exposure of the human body to UFP effects could be widespread. The size of the specific particulate matter allows its penetration to system blood stream. Organs, such as the liver, could also be considered as organ-targets according to recent studies. What is most impressive and scientifically challenging is the latest evidence suggesting possible penetration of particles of this size (UFP, $<0.1 \mu \mathrm{m}$ ) to the brain and central nervous system.

\section{REFERENCES}

Baggs R.B., Ferin J., Oberdorster G. (1997), Regression of pulmonary lesions produced by inhaled titanium dioxide in rats, Veterinary Pathology, 34(6), 592-597.

Baron P.A. and Willeke K. Eds. (2001), Aerosol Measurement: Principles, Techniques and Applications. New York, van Nostrand Reinhold.

Beck-Speier I., Dayal N., Karg E., Maier K.L., Roth C., Ziesenis A., Heyder J. (2001), Agglomerates of ultrafine particles of elemental carbon and $\mathrm{TiO} 2$ induce generation of lipid mediators in alveolar macrophages, Environmental Health Perspectives, 109, 613-618.

Bockhorn H. (2000), Ultrafine particles from combustion sources: approaches to what we want to know, Philosophical Transactions of the Royal Society of London, A 358, 2659-2672.

Bodian D., Howe H.A. (1941a), Experimental studies on intraneural spread of poliomyelitis virus. In: Bulletin of the Johns Hopkins Hospital, Bordley, J.I. (ed.), Baltimore: The Johns Hopkins Press, 248-267.

Bodian D., Howe H.A. (1941b), The rate of progression of poliomyelitis virus in nerves, Baltimore: The Johns Hopkins Press, 79-85.

Boland S., Bonvallot, V., Fournier T., Baeza-Squiban A., Aubier M., Marano F. (2000), Mechanisms of GM-F increase by diesel exhaust particles in human airway epithelial cells, American Journal of Physiology-Lung Cellular and Molecular Physiology, 278(1), L25-L32.

Brown D.M., Wilson M.R., MacNee W., Stone V., Donaldson K. (2001), Size-dependent proinflammatory effects of ultrafine polystyrene particles: A role for surface area and oxidative stress in the enhanced activity of ultrafines, Toxicology and Applied Pharmacology, 175(3), 191-199.

Brown J.S., Zeman K.L., Bennett W.D. (2002), Ultrafine particle deposition and clearance in the healthy and obstructed lung, American Journal of Respiratory and Critical Care Medicine, 166(9), 1240-1247.

Brunshidle T.P., Konowalchuk B., Nabeel I., Sullivan J.E. (2003), A Review of the Measurement, Emission, Particles: Characteristics and potential human Health Impacts of Ultrafine Particle, http://enhs.umn.edu/5103/particles/character.html.

Cassee F.R., Arts J.H E., Fokkens P.H.B., Spoor S.M., Boere A.J F., Van Bree L., Dormans J.A.M.A. (2002), Pulmonary effects of ultrafine and fine ammonium salts aerosols in healthy and monocrotaline-treated rats following short-term exposure, Inhalation Toxicology, 14(12), 1215-29.

CCOHS, Canadian Centre for Occupational Health and Safety. (1999), How do particulates enter the respiratory system?, http://www.ccohs.ca/oshanswers/chemicals/how_do.html.

Churg A., Stevens B., Wright J.L. (1998), Comparison of the uptake of fine and ultrafine $\mathrm{TiO}_{2}$ in a tracheal explant system, American Journal of Physiology-Lung Cellular and Molecular Physiology, 18(1), L81-L86.

Churg A., Gilks B., \& Dai J. (1999). Induction of fibrogenic mediators by fine and ultrafine titanium dioxide in rat tracheal explants, American Journal of Physiology-Lung Cellular and Molecular Physiology, 277(5), L975-L982.

DeLorenzo J. (1957), Electron microscopic observations of the olfactory mucosa and olfactory nerve, J Biophys Biochem Cytol, 3, 839-850.

Diapouli E., Chaloulakou A., Spyrellis N. (2008), Indoor and outdoor PM concentrations at a residential environment, in the Athens area, Global NEST Journal, 10(2), 201-208. 
Dick C.A. J., Brown D.M., Donaldson K., Stone V. (2003), The role of free radicals in the toxic and inflammatory effects of four different ultrafine particle types, Inhalation Toxicology, 15(1), 3952.

Dorman D.C., McManus B.E., Parkinson C.U., Manuel C.A., McElveen A.M., Everitt J.I. (2004), Nasal toxicity of manganese sulfate and manganese phosphate in young male rats following subchronic (13-week) inhalation exposure, Inhalation Toxicology, 16, 481-488.

Frampton M.W., Voter K.Z., Morrow P.E., Roberts N.J. Jr, Culp D.J., Cox C., Utell M.J. (1992), Sulfuric acid aerosol exposure in humans assessed by bronchoalveolar lavage, American Review of Respiratory Disease, 146, 626-632.

Frampton M.W. (2001), Systemic and cardiovascular effects of airway injury and inflammation: Ultrafine particle expolure in humans, Environmental Health Perspective, 109(suppl 4), 529532.

Guo L., Lewis J.O., McLaughlin J.P. (2008). Emissions from Irish domestic fireplaces and their impact on indoor air quality when used as supplementary heating source, Global NEST Journal, 10(2), 209-216.

Henriksson J., Tjalve H. (2000), Manganese taken up into the CNS via the olfactory pathway in rats affects astrocytes, Toxicol Sci, 55, 392-398.

Hofmann W., Morawska L., Bergmann R. (2001), Environmental tobacco smoke deposition in the human respiratory tract: Differences between experimental and theoretical approaches, Journal of Respiratory Medicine, 14(3), 317-326.

Hoi K.I., Yen K.V., Mok K.M. (2008), Kalman filter based prediction system for wintertime $\mathrm{PM}_{10}$ concentration in Macau, Global NEST Journal, 10(2), 140-150.

Holgate S.T., Sandstrom T., Frew A.J., Stenfors N., Nordenhall C., Sundeep S., Soderberg M. (2002), Health effects of acute exposure to air pollution, Part 1: Healthy and asthmatic subjects exposed to diesel exhaust, Boston: Health Effects Institute.

Ibald-Mulli, A., Wichmann, H. E., Kreyling, W, Peters, A. (2002), Epidemiological evidence on health effects of ultrafine particles, Journal of Aerosol Medicine, 15(2), 189-201.

Kawasaki S., Takizawa H., Takami K., Desaki M., Okazaki H., Kasama T., Kobayashi K., Yamamoto K., Nakahara K., Tanaka M., Sagai M., Ohtoshi T. (2001), Benzene-extracted components are important for the major activity of diesel exhaust particles - Effect on interleukin-8 gene expression in human bronchial epithelial cells, American Journal of Respiratory Cell and Molecular Biology, 24(4), 419-426.

Kim C.S. and Jaques P.A. (2000), Respiratory dose of inhaled ultrafine particles in healthy adults, Philosophical Transactions of the Royal Society of London Series a-Mathematical Physical and Engineering Sciences, 358(1775), 2693-2705.

Kim H.J., Liu X.D., Kobayashi T., Kohyama T., Wen F-Q., Romberger D.J., Conner H., Gilmour P.S., Donaldson K., MacNee W., Rennard S.I. (2003), Ultrafine carbon black particles inhibit human lung fibroblast-mediated collagen gel contraction, American Journal of Respiratory Cell and Molecular Biology, 28(1), 111-121.

Koulouri E., Grivas G., Gerasopoulos E., Chaloulakou A., Mihalopoulos N., Spyrellis N. (2008), Study of size-segregated particle $\left(\mathrm{PM}_{1}, \mathrm{PM}_{2,5}, \mathrm{PM}_{10}\right)$ concentrations over Greece. Global NEST Journal, 10(2), 132-139.

Maraziotis E., Sarotis L., Marazioti C., Marazioti P.(2008), Statistical analysis of inhalable $\left(\mathrm{PM}_{10}\right)$ and fine particles $\left(\mathrm{PM}_{2.5}\right)$ concentrations in urban region of Patras Greece, Global NEST Journal, 10(2), 123-131.

Moller W., Hofer T., Ziesenis A., Karg E., Heyder J. (2002), Ultrafine particles cause cytoskeletal dysfunctions in macrophages, Toxicology and Applied Pharmacology, 182(3), 197-207.

Morawska L., Bofinger N., Kosic L., Nwankowala A. (1998), Submicron and supermicron particles from diesel vehicle emissions, Environmental Science \& Technology, 32(14), 2033-2042.

Morawska L., Thomas S., Gilbert D., Greenaway C. and Rijnders E. (1999), A study of the horizontal and vertical profile of submicrometer particulates in relation to a busy road. Atmospheric Environment, 33(8), 1261-1274

Morawska L., Moore M.R., Ristovski Z.D. (2004), Desktop Literature Review and Analysis: Health Impacts of Ultrafine Particles. For the Australian Department of the Environment and Heritage, ISBN 064255055 7, 1-207.

Nemmar A., Delaunois A., Nemery B., Dessy-Doize C., Beckers J-F., Sulon J., Gustin P. (1999), Inflammatory effect of intratracheal instillation of ultrafine particles in the rabbit: Role of Cfiber and mast cells, Toxicology and Applied Pharmacology, 160(3), 250-261. 
Nemmar A., Hoet P.H.M., Vanquickenborne B., Dinsdale D., Thomeer M., Hoylaerts M.F., Vanbilloen H., Mortelmans L., Nemery B. (2002), Passage of inhaled particles into the blood circulation in humans, Circulation, 105, 411-414.

NSC, National Safety Council. (1994), Air pollution Fact Sheet (for New Drivers), Environmental Health Center, Washington, DC.USA, www.nsc.org/ehc/mobile/airpollu.htm.

Oberdorster G. (1996), Significance of particle parameters in the evaluation of exposure-doseresponse relationships of inhaled particles, Inhalation Toxicology, 8(Suppl), 73-89.

Oberdörster G., Finkelstein J.N., Johnston C.,Gelein R., Cox C., Baggs R., Elder A.C.P. (2000), HEI research report: Acute pulmonary effects of ultrafine particles in rats and mice, Research Report 96, August Health Effects Institute.

Oberdorster G., Utell M.J. (2002), Ultrafine Particles in the Urban Air: To the Respiratory Tract And Beyond?, Enviromental Health Perspectives, 110(8), 440-441.

Oberdorster G., Sharp Z., Atudorei V., Elder A., Gelein R., Kreyling W., Cox C. (2004), Translocation of inhaled ultrafine particles to the brain, Inhalation Toxicology, 16(6/7),437445.

Oberdorster G., Oberdorster E., Oberdorster J. (2005). Nanotoxicology: an emerging discipline evolving from studies of ultrafine particles, Environ Health Perspect, 113, 823-839.

Osier M. and Oberdorster G. (1997), Intratracheal inhalation vs intratracheal instillation: Differences in particle effects, Fundamental and Applied Toxicology, 40(2), 220-227.

Osunsanya T., Prescott G., Seaton A. (2001), Acute respiratory effects of particles: mass or number?, Occupational and Environmental Medicine, 58(3), 154-159.

Pekkanen, J., Timonen, K. L., Ruuskanen, J., Reponen, A., Mirme, A. (1997), Effects of ultrafine and fine particles in urban air on peak expiratory flow among children with asthmatic symptoms, Environmental Research, 74(1), 24-33.

Pekkanen J., Schindler C., Schwartz J. (2001), Confounding and effect modification in the shortterm effects of ambient particles on total mortality: results from 29 European cities within the APHEA2 project, Epidemiology, 12, 521-531.

Pekkanen J., Peters A., Hoek G., Tiittanen P., Brunekreef B., de Hartog J., Heinrich J., Ibald-Mulli A., Kreyling W. G., Lanki T., Timonen K L., Vanninen E. (2002), Particulate air pollution and risk of ST-segment depression during repeated submaximal exercise tests among subjects with coronary heart disease. The exposure and risk assessment for fine and ultrafine particles in ambient air (ULTRA) study, Circulation, 106(8), 933-938.

Penttinen P., Timonen K.L., Tittanen P., Mirme A., Ruuskanen J., Pekkanen J. (2001), Number concentration and size of particles in urban air: Effects on spirometric lung function in adult asthmatic subjects, Environmental Health Perspectives, 109(4), 319-323.

Peters A., Doring A., Wichmann H-E., Koenig W, (1997), Increased plasma viscosity during an air pollution episode: A link to mortality?, Lancet, 349(9065), 1582-1587.

Polymeneas P. and Pilinis C., (2008), Athens air quality and importance of biogenic emissions: a case study, Global NEST Journal, 10(2), 151-160.

Pope C.A. (2000), Epidemiology of fine particulate air pollution and human health: biologic mechanisms and who's at risk?, Environ Health Persp, 108(Suppl 4), 713-723.

Reibman J., Hsu Y.S., Chen L.C., Kumar A., Su W.C., Choy W., Talbot A., Gordon T. (2002), Size fractions of ambient particulate matter induce granulocyte macrophage colony-stimulating factor in human bronchial epithelial cells by mitogen-activated protein kinase pathways, American Journal of Respiratory Cell and Molecular Biology, 27(4), 455-462.

Ristovski Z., Morawska L., Thomas S., Hitchins J., Greenaway C. Gilbert, D. (2000), Particle emissions from natural gas engines, Journal of Aerosol Science, 31, 403-413.

Salvi S., Holgate, S. (1999), Mechanisms of particulate matter toxicity, Clin Exp Allergy, 29, 11871194.

Samet J.M., Zeger, S.L., Dominici F., Curriero F., Coursac I., Dockery D.W., Schwartz J., Zanobetti A. (2000), The National Morbidity, Mortality, and Air Pollution Study. Part II: Morbidity and mortality from air pollution in the United States. Health Effects Institute. 94 Part II,1-82. North Andover MA, Flagship Press.

Seinfeld J.H. and Pandis S.N., (2006), Atmospheric Chemistry and Physics: From Air Pollution to Climate Change. New York, NY: Wiley-Interscience, ISBN: 0471720178.

Stone V., Brown D.M., Watt N., Ritchie H., Wilson M., Donaldson K. (2000), Ultrafine particlemediated activation of macrophages: intracellular calcium signaling and oxidative stress, Inhalation Toxicology, 12(Suppl. 3), 345-351.

Takenaka S., Karg E., Muller W., Roth C., Ziesenis A., Heinzmann U., Scramel P., Heyder J. (2000), A morphologic study on the fate of ultrafine silver particles: Distribution pattern of 
phagocytized metallic silver in vitro and in vivo, Inhalation Toxicology, 12, 291-299.

Takenaka S., Karg E., Roth C., Schulz H., Ziesenis A., Heinzmann U., Schramel P., Heyder J. (2001), Pulmonary and systemic distribution of inhaled ultrafine silver particles in rats, Environmental Health Perspectives, 109, 547-551.

Timblin C.R., Shukla A., Berlanger I., Berube K.A., Churg A., Mossman B.T. (2002), Ultrafine airborne particles cause increases in protooncogene expression and proliferation in alveolar epithelial cells, Toxicology and Applied Pharmacology, 179(2), 98-104.

Tjalve H, Mejare C, Borg-Neczak K. (1995), Uptake and transport of manganese in primary and secondary olfactory neurons in pike, Pharmacol Toxicol, 77(1), 23-31.

Tjalve H., Henriksson J., Tallkvist J., Larsson B.S., Lindquist N.G. (1996), Uptake of manganese and cadmium from the nasal mucosa into the central nervous system via olfactory pathways in rats, Pharmacol Toxicol, 79, 347-356.

Tjalve H, Henriksson J. (1999), Uptake of metals in the brain via olfactory pathways, Neurotoxicology, 20(2-3), 181-196.

US EPA, US Environmental Protection Agency. (1996), Air quality criteria for particulate matter, Research Triangle Park, NC: National Center for Environmental Assessment, RTP Office; reports nos EPA/600/P-95/001aF-cF.

Veronesi B., de Haar C., Lseng L., Oortgiesen M. (2002), The surface charge of visible particulate matter predicts biological activation in human bronchial epithelial cells, Toxicology and Applied Pharmacology, 178(3), 144-154.

WHO, World Health Organization. (1997), Air Quality Guidelines for Europe 1996: particulate matter. Final edited draft, p. 84.

WHO, World Health Organization. (1999a), Health Guidelines for Vegetation Fire Events, Geneva, Switzerland.

WHO, World Health Organization. (1999b), Guidelines for Air Quality, Geneva, Switzerland.

Wichmann H.E., Spix C., Tuch T., Wölke G., Peters A., Heinrich J., Kreyling W.G., Heyder J. (2000), Daily mortality and fine and ultrafine particles in erfurt, germany, Part I: role of particle number and particle mass, Research report, 98, 5-86.

Wilson M.R., Lightbody J.H., Donaldson K., Sales J., Stone V. (2002), Interactions between Ultrafine Particles and Transition Metals in Vivo and in Vitro, Toxicology and Applied Pharmacology, 184(3), 172-179.

Yang Y., Li X., Li Y.L., Tan M., Lu W., Zhang G., Li Y. (2008), Platinum concentrations in urban airborne particles from Shanghai, China, Global NEST Journal, 10(2), 169-173.

Zimmer A.T., Baron P.A., Biswas P. (2002), The influence of operating parameters on numberweighted aerosol size distribution generated from a gas metal arc welding process, J Aerosol Sci, 33, 519-53. 